\title{
Cariogram and Oratest in Caries Risk Assessment for School Children
}

\begin{abstract}
Keywords
Caries activity tests; Caries risk factors; Cariogram; Oratest; Risk assessment.

Abstract

Aims and objectives: The present study was carried out to evaluate the correlation between Cariogram and Oratest in caries risk assessment among school children.

Materials and Methods: A clinical diagnostic trial including 240 healthy school children using Cariogram and Oratest to predict the dental carie risk for each individual. The data required for Cariogram construction (diet contents and frequency, the related general diseases, the use of fluoridated toothpaste, tooth brushing and other fluoride supplements, past denta history and dental plaque scores) were collected by dietary questionnaire, interview and clinical examination. Oratest was carried out for the same patients after performing the Cariogram. The analysis of collected data was performed using SPSS version 22 software program. The $p$-values $\leq 0.05$ was considered statistically significant.
\end{abstract}

Results: There were statistically significant differences for all risk factors and Oratest scores between low and high caries risk individuals classified by Cariogram. A highly significant positive correlation between the green sector of Cariogram (chance of avoiding development of caries in future) and Oratest scores, highly significant negative correlations between both Cariogram and Oratest and dental caries status were found. Children with Oratest time less than 64.43 minutes are at high caries risk.

Conclusion: The present study indicated that Oratest has a definite clinical relationship with the green sector of Cariogram of each individual and can be used as a separate test for predicting caries susceptibility.

\section{Introduction}

Dental caries has a multi factorial etiology, host including saliva and teeth, the microflora or biofilm, the substrate as diet and time. The modifiable risk factors can be modified and amenable to intervention. Whereas, the non-modifiable risk factors are quite challenging to health care professionals [1]. Understanding caries etiology and its progression is very important for planning preventive programs for dental caries and this has been made easy with concomitant advances in science and technology $[2,3]$.

Dental caries risk model is used when it is important to identify one or more risk factors for the disease so that likely points for intervention can be planned. A prediction model, on the contrary, is used when one is mainly interested in identifying who is at high risk. The main goal is to maximize sensitivity and specificity of the prediction, so that any good predictor may be included in the model. A challenge for the biological factor approach is to correctly summarize the complex picture of the various inter-related caries risk factors, so that it can easily be used by the dental professional routinely in the dental clinics $[4,5]$.

The concept of prediction of human dental caries risk has existed for many years, particularly, during the past twenty years where the

\section{Journal of Oral Biology}

\author{
Wahdan M. Elkwatehy ${ }^{1 *}$ and Rabab I Salama ${ }^{2}$ \\ ILecturer of Dental Public Health, Faculty of dentistry, Mansoura \\ University, Egypt \\ 2Assistant professor of Dental Public Health, Faculty of dentistry, \\ Mansoura University, Egypt \\ ${ }^{*}$ Address for Correspondence \\ Wahdan M. Elkwatehy, Faculty of Dentistry, Department of Public \\ Health and Preventive Dentistry, Mansoura University, Egypt, Tel: \\ 00201000993389; E-mail: wahdanelkwatehy@yahoo.com \\ Submission: 19 April, 2018 \\ Accepted: 21 May, 2018 \\ Published: 31 May, 2018 \\ Copyright: () 2018 Elkwatehy WM, et al. This is an open access article \\ distributed under the Creative Commons Attribution License, which \\ permits unrestricted use, distribution, and reproduction in any medium, \\ provided the original work is properly cited.
}

interest in this issue has been increased. This appears to reflect recent advances in the knowledge of the etiology of dental caries, thus the caries prediction will be more accurate and depend on certain specific risk factors or their combinations. The desire to prevent rather than to treat dental caries should be take the priority of dental health care workers but at the same time the increasing need of cost should be understood and put in their consideration $[6,7]$.

The Oratest is a potential whole mouth diagnostic test to measure microbial load in intraoral diseases of epidemiological importance like periodontal disease and caries. It can be used as a simple, inexpensive and rapid technique for assessing caries activity since a significant relationship exists clinically with caries status and microbiologically with the streptococcus mutans count of the individual $[8,9]$.

It has been hypothesized that Oratest is based on the rate of oxygen depletion by micro-organisms. Under aerobic conditions the bacterial enzyme; aerobic dehydrogenase transfers electrons or protons to oxygen. Once oxygen gets utilized by the aerobic organisms and an anaerobic environment is attained, methylene blue (redox indicator) acts as an electron acceptor and gets reduced to leukomethylene blue. The metabolic activity of the aerobic microorganism is reflected by the reduction of methylene blue to leukomethylene blue [10].

Caries risk assessment has moved from depend on individual risk factor to an approach in which all risk factors are weighted based on the putative role they play in the etiology of the dental disease $[11,12]$. Among the caries risk prediction models available is the cariogram which graphically determine the chance of an individual avoiding caries in the near future $[13,14]$. Many studies indicated that, Cariogram was more accurate in predicting caries than any single factor and had shown promising results in predicting caries in children $[15,16]$.

The lack of sufficient studies to evaluate the effectiveness of Oratest as a risk assessment test in comparison with a well approved caries risk assessment model is the main reason why this is not universally acceptable in spite of its advantages and potential, so the present study conducted to validate the effectiveness of this technique in relation to Cariogram for caries risk assessment. 


\section{Aim of the Work}

The present study was carried out to:

a) Provide an insight of how a simple oral rinse test (Oratest) can be used for detection of caries activity.

b) Evaluate the correlation between it and multifactorial risk assessment model (Cariogram).

\section{Materials and Methods}

The present study is a clinical diagnostic trial to evaluate the effectiveness of Oratest to predict caries activity among children. The present study was started at the beginning of February 2017 and ended by the end of May 2017.

\section{Sample size}

The target population was school children from (6-12) years old participating in health education school based program carried out by the researchers. By calculation of the sample size at confidence interval $95 \%$ and confidence level of 5\%, the estimated sample was 217 which increased to 240 children.

\section{Sample selection}

A total of 240 healthy school children of both gender with an age range from 6-12 years were selected. The selected children were not taking antibiotics or using mouth rinses within the two months preceding the study. Before starting the study the ethical approval was obtained from Ethical Committee, Faculty of Dentistry, Mansoura University, also written informed consents were obtained from the school authority and children's parents.

\section{Risk assessment according to cariogram}

Dietary information was collected from a weekly dietary questionnaire completed by each participant to record the amount, type and frequency of the foods consumed for a week. Interview were employed to collect data related to general diseases, the use of fluoridated toothpaste, tooth brushing habits and other fluoride supplements (Table 1).

Dental caries for each participant was visually assessed using WHO criteria [17]. The caries experience was calculated as the summation of DMFT+deft [18,19]. The normal past dental history for this age group was considered when dental caries experience $=3-4$.

Dental plaque was assessed according to Sillness and loe Plaque Index criteria [20]. Saliva samples were collected according to a standardized method, the child was asked to sit comfortably on the dental chair in an erect position. After swallowing the preexisting saliva in the oral cavity, a standardized piece of gum base (nearly one gram) was given to the child. The stimulated saliva secreted in the subsequent ( 5 min) was collected while the child chewed on the same block of gum base. The child was asked to spit and drool in a disposable sterile cup held near the mouth. The stimulated salivary flow rate was calculated as amount of saliva/collection time $=\mathrm{ml} / \mathrm{min}[21]$.

Streptococcus mutans level was detected using chair-side method/ Dentocult Strip Mutans (DSM). According to the instructions of the manufacturer, the plastic DSM strips were rotated 10 times directly on the tongue, withdrawn through lightly closed lips and then cultivated
Table 1: Cariogram five sectors and their variables including the instruments used for measurements.

\begin{tabular}{|c|c|c|c|}
\hline Score & Variable & $\begin{array}{c}\text { Instrument } \\
\text { used }\end{array}$ & Sectors \\
\hline \multirow[t]{2}{*}{$\begin{array}{l}\text { Circumstance } \\
\text { (Yellow } \\
\text { sector) }\end{array}$} & Caries experience & $\begin{array}{l}\text { DMFT of the } \\
\text { population by } \\
\text { age }\end{array}$ & $\begin{array}{l}\text { 0: No caries experience } \\
\text { 1: Lower than the age } \\
\text { group range } \\
\text { 2: Within the age group } \\
\text { range } \\
\text { 3: Higher than the age } \\
\text { group range }\end{array}$ \\
\hline & Related diseases & $\begin{array}{c}\text { Face to face } \\
\text { interview }\end{array}$ & $\begin{array}{l}\text { 0: No caries-related } \\
\text { disease } \\
\text { 1: Related disease-Mild } \\
\text { degree } \\
\text { 2: Related disease-Severe } \\
\text { degree }\end{array}$ \\
\hline \multirow[t]{2}{*}{$\begin{array}{l}\text { Diet } \\
\text { (Dark blue } \\
\text { sector) }\end{array}$} & Diet content & $\begin{array}{l}\text { Weekly diet } \\
\text { diary }\end{array}$ & $\begin{array}{l}0 \text { : Very low amount of } \\
\text { sugar } \\
\text { 1: Low amount } \\
\text { 2: Moderate amount } \\
\text { 3: High amount }\end{array}$ \\
\hline & Diet frequency & $\begin{array}{c}\text { Weekly diet } \\
\text { diary }\end{array}$ & $\begin{array}{l}\text { 0: } 0 \text { to } 3 \text { daily intakes } \\
\text { 1: } 4 \text { to } 5 \text { daily intakes } \\
\text { 2: } 6 \text { to } 7 \text { daily intakes } \\
\text { 3: More than } 7 \text { daily } \\
\text { intakes }\end{array}$ \\
\hline \multirow[t]{2}{*}{$\begin{array}{c}\text { Bacteria } \\
\text { (Red sector) }\end{array}$} & Plaque quantity & $\begin{array}{l}\text { Silness - Löe } \\
\text { plaque index }\end{array}$ & $\begin{array}{l}\text { 0: No plaque accumulation } \\
\text { 1: Mild plaque } \\
\text { accumulation } \\
\text { 2: Moderate plaque } \\
\text { accumulation } \\
\text { 3: Heavy plaque } \\
\text { accumulation }\end{array}$ \\
\hline & $\begin{array}{l}\text { Streptococcus } \\
\text { Mutans level }\end{array}$ & $\begin{array}{l}\text { Dentocult-SM } \\
\text { Strip Mutans }\end{array}$ & $\begin{array}{l}\text { Class } 0=<10^{4} \mathrm{CFU} \\
\text { Class } 1=\geq 10^{4}-<10^{5} \mathrm{CFU} \\
\text { Class } 2=\geq 10^{5}-<10^{6} \mathrm{CFU} \\
\text { Class } 3=>10^{6} \mathrm{CFU}\end{array}$ \\
\hline \multirow[t]{2}{*}{$\begin{array}{l}\text { Susceptibility } \\
\text { (Light blue } \\
\text { sector) }\end{array}$} & Fluoride program & $\begin{array}{c}\text { Oral health } \\
\text { questionnaire } \\
\text { (Clinical record) }\end{array}$ & $\begin{array}{l}\text { 0: Complete fluoride } \\
\text { program } \\
\text { 1: Irregular but complete } \\
\text { fluoride program } \\
\text { 2: Only dentifrices } \\
\text { 3: No fluoride supplements }\end{array}$ \\
\hline & Salivary secretion & $\begin{array}{l}\text { Stimulated } \\
\text { saliva } \\
\text { Test }\end{array}$ & $\begin{array}{l}0:>1.1 \mathrm{ml} / \mathrm{min} \\
1: 0.9-1.1 \mathrm{ml} / \mathrm{min} \\
2: 0.5-0.9 \mathrm{ml} / \mathrm{min} \\
3:<0.5 \mathrm{ml} / \mathrm{min}\end{array}$ \\
\hline
\end{tabular}

in a vial of selective culture broth for 48 hours. The growth was scored in four levels (0-3) based on the density on the strip (Table 1).

Data concerning the seven factors considered in this study were fed into the Cariogram software. To avoid bias, clinical judgment, which was based on the opinion of the clinician, was set to (1) for all patients. Once information was entered into the program, a pie chart was showed a green area of the chart indicating the "actual chance to avoid new cavities" was automatically generated.

\section{Risk assessment according to Oratest}

Oratest was carried out for the same patients after performing the Cariogram. Each patient was given $10 \mathrm{ml}$ of ultrahigh temperature sterilized cow milk in a beaker and asked to rinse the mouth vigorously for 30 seconds. The expectorated milk was collected in the same beaker and $3 \mathrm{ml}$ of expectorate was aspirated with the help of a disposable syringe, $0.12 \mathrm{ml}$ of $0.1 \%$ methylene blue was added to a sterile screw cap test tube. The expectorated milk was transferred to 
the test tube and thoroughly mixed, and placed on a stand in a well illuminated area over a mirror at room temperature. Test tubes were observed every $10 \mathrm{~min}$ for color change at the bottom, which would easily be discernible in the mirror. Time taken for initial color change within a $6 \mathrm{~mm}$ diameter circle on the bottom of the test tube was recorded [22].

\section{Statistical analysis}

After data collection, the subjects were classified into low and high caries risk groups according to the green sector percentage of the Cariogram. Chi square test was used to compare frequencies of different scores of risk factors. Mann-Whitney test was used to compare between low and high caries risk groups as regards the green sector, Oratest time and dental caries experience scores. To explore potential associations between Cariogram values (green sector), the time scores obtained by the Oratest and dental caries experience, Spearman's correlation coefficients were calculated. All analyses were performed using SPSS for Windows V.22 (IBM Inc., Chicago, USA). The $\mathrm{p}$-values equal or less than 0.05 was considered significant.

\section{Results}

The green sector of Cariogram for each individual was detected. Then subjects were classified into two caries risk groups according to the green sector percentage shown by the Cariogram: low caries risk group (green sector more than 50\%) and high caries risk group (green sector equal or less than $50 \%$ ). There were statistically significant differences between the two sectors regarding all variables of cariogram except the general health condition (related diseases) (Table 2).

Comparison between the high caries risk and low caries risk groups classified by Cariogram indicated that, the mean green sectors were 58.87 and 21.52, the mean Oratest times were 170.45 and 64.43 min. and the mean caries experience was 1.49 and 6.33 for low caries and high caries risk groups respectively. Significant differences were found between low and high caries sectors regarding cariogram variables, Oratest time and dental caries experience as evident in Table 3.

Testing the correlation between cariogram, Oratest and dental caries experience revealed that, the Oratest time (min) exhibited a statistically highly significant positive linear relationship with Cariogram green sector. Both Oratest time and Cariogram green sector were found to be in a statistically highly significant negative linear relationship with dental caries experience (Table 4) (Figures 1-3). The sensitivity of predicting high caries risk individuals was $97 \%$ with $95 \%$ confidence interval $(\mathrm{CI})=19.50-23.54$ for Cariogram and 88 \% with $\mathrm{CI}=56.66-72.17$ for the Oratest. The specificity was $80 \%$ with $\mathrm{CI}=56.86-60.88$ for Cariogram and $85 \%$ with $\mathrm{CI}=163.71-177.19$ for Oratest (Table 5).

\section{Discussion}

In the modern era of early detection of dental caries, there is a need for rapid and accurate method for detection of caries activity and future caries risk. The present study was concerned with the evaluation of the effectiveness of Oratest as a simple caries predictive method compared to the Cariogram.
Table 2: Cariogram: input variables, scores and Chi square test compare between different scores in each variable.

\begin{tabular}{|c|c|c|c|c|c|c|}
\hline \multirow[b]{2}{*}{ Variables } & \multirow[b]{2}{*}{ Scoring } & \multicolumn{5}{|c|}{ Caries risk } \\
\hline & & $\begin{array}{c}\text { Green } \\
\text { sector }> \\
50 \% \\
(\mathrm{No}=93)\end{array}$ & $\begin{array}{c}\text { Green } \\
\text { sector } \leq \\
50 \% \\
(\text { No }=147)\end{array}$ & $\begin{array}{c}\text { Total } \\
\text { No }= \\
240\end{array}$ & $\%$ & $\mathbf{P}$ \\
\hline \multirow{2}{*}{ Gender } & Male & 30 & 71 & 101 & 42 & \multirow[b]{2}{*}{0.067} \\
\hline & Female & 63 & 76 & 139 & 58 & \\
\hline \multirow{3}{*}{$\begin{array}{l}\text { Related } \\
\text { diseases }\end{array}$} & 0: Normal & 93 & 147 & 240 & 100 & \multirow[b]{3}{*}{0.380} \\
\hline & 1: Mild effect & 0 & 0 & 0 & 0 & \\
\hline & 2: Sever effect & 0 & 0 & 0 & 0 & \\
\hline \multirow{4}{*}{$\begin{array}{l}\text { Dental caries } \\
\text { experience }\end{array}$} & $\begin{array}{l}\text { 0: No caries } \\
\text { experience }\end{array}$ & 3 & 0 & 3 & 1.3 & \multirow{4}{*}{0.000} \\
\hline & $\begin{array}{l}\text { 1: Better than } \\
\text { the normal } \\
\text { range }\end{array}$ & 13 & 8 & 21 & 8.7 & \\
\hline & $\begin{array}{l}\text { 2: Within the } \\
\text { normal range }\end{array}$ & 77 & 10 & 87 & 36.2 & \\
\hline & $\begin{array}{l}\text { 3: Worse than } \\
\text { the normal } \\
\text { range }\end{array}$ & 0 & 129 & 129 & 53.8 & \\
\hline \multirow{4}{*}{ Diet content } & 0: Very low & 0 & 0 & 0 & 0 & \multirow{4}{*}{$\begin{array}{c}0 \\
.000\end{array}$} \\
\hline & 1: Low & 49 & 3 & 52 & 21.6 & \\
\hline & 2: Moderate & 44 & 47 & 91 & 37.9 & \\
\hline & 3: High & 0 & 97 & 97 & 40.5 & \\
\hline \multirow{4}{*}{ Diet frequency } & $0: 0$ to 3 & 0 & 0 & 0 & 0 & \multirow{4}{*}{0.002} \\
\hline & $1: 4$ to 5 & 62 & 0 & 62 & 25.8 & \\
\hline & 2: 6 to 7 & 31 & 45 & 76 & 31.7 & \\
\hline & 3: more than 7 & 0 & 102 & 102 & 42.5 & \\
\hline \multirow{4}{*}{ Plaque Index } & 0: Normal & 3 & 0 & 3 & 1.3 & \multirow{4}{*}{0.020} \\
\hline & 1: Mild & 57 & 16 & 73 & 30.4 & \\
\hline & 2: Moderate & 31 & 39 & 70 & 29.1 & \\
\hline & 3: High & 2 & 92 & 94 & 39.2 & \\
\hline \multirow{4}{*}{$\begin{array}{l}\text { Streptococcus } \\
\text { Mutans count }\end{array}$} & $\begin{array}{l}\text { Class } 0=<10^{4} \\
\text { CFU }\end{array}$ & 73 & 0 & 73 & 30.4 & \multirow{4}{*}{0.000} \\
\hline & $\begin{array}{l}\text { Class } 1=\geq 10^{4}- \\
<10^{5} \mathrm{CFU}\end{array}$ & 17 & 12 & 29 & 12.1 & \\
\hline & $\begin{array}{l}\text { Class } 2=\geq 10^{5}- \\
<10^{6} \mathrm{CFU}\end{array}$ & 3 & 37 & 40 & 16.7 & \\
\hline & $\begin{array}{l}\text { Class } 3=>10^{6} \\
\text { CFU }\end{array}$ & 0 & 98 & 98 & 40.8 & \\
\hline \multirow{4}{*}{$\begin{array}{l}\text { Fluoride } \\
\text { program }\end{array}$} & 0: Complete & 19 & 0 & 19 & 7.9 & \multirow{4}{*}{0.001} \\
\hline & $\begin{array}{l}\text { 1: Complete } \\
\text { irregular }\end{array}$ & 64 & 0 & 64 & 26.7 & \\
\hline & $\begin{array}{l}\text { 2: Only } \\
\text { toothpaste }\end{array}$ & 9 & 53 & 62 & 25.8 & \\
\hline & 3: No fluoride & 1 & 94 & 95 & 39.6 & \\
\hline \multirow{4}{*}{$\begin{array}{l}\text { Stimulated } \\
\text { saliva }\end{array}$} & $0:>1.1 \mathrm{ml} / \mathrm{min}$ & 52 & 21 & 73 & 30.4 & \multirow{4}{*}{0.001} \\
\hline & $\begin{array}{l}1: 0.9-1.1 \mathrm{ml} / \\
\min \end{array}$ & 35 & 26 & 61 & 25.4 & \\
\hline & $\begin{array}{l}\text { 2: } 0.5-0.9 \mathrm{ml} / \\
\min \end{array}$ & 6 & 37 & 43 & 17.9 & \\
\hline & $3:<0.5 \mathrm{ml} / \mathrm{min}$ & 0 & 63 & 63 & 26.3 & \\
\hline
\end{tabular}

$p=p$-values were calculated by Chi Square test and considered to be significant at $p \leq 0.05$.

Cariogram is a reliable tool in caries prediction which has been validated in school children, adults and the elderly [23-26]. It can aid in identifying different risk groups in a community and developing preventive strategies for reducing caries risk in children, however multiple variables should be evaluated and fed the Cariogram to 
Table 3: Mean and standard deviation of the high caries risk and low caries risk sectors as classified by Cariogram.

\begin{tabular}{|c|c|c|c|c|c|}
\hline \multicolumn{2}{|c|}{ Groups } & Frequency & Cariogram & Oratest & $\begin{array}{c}\text { Dental caries } \\
\text { experience }\end{array}$ \\
\cline { 4 - 6 } & Mean \pm SD & Mean \pm SD & Mean \pm SD \\
\hline $\begin{array}{c}\text { Low } \\
\text { risk } \\
(\text { Green } \\
\text { sector } \\
>50 \%)\end{array}$ & Very low & 25 & $78.00 \pm 1.50$ & $203.56 \pm 24.80$ & $0.11 \pm 0.33$ \\
\hline \multicolumn{2}{|c|}{ Total } & 68 & $54.34 \pm 3.38$ & $162.10 \pm 30.03$ & $1.82 \pm 0.87$ \\
\hline $\begin{array}{c}\text { High } \\
\text { risk }\end{array}$ & Moderate & 49 & $38.17 \pm 7.01$ & $118.03 \pm 36.04$ & $4.03 \pm 1.27$ \\
\hline $\begin{array}{c}\text { Green } \\
\text { sector } \\
\leq 50 \%)\end{array}$ & High & 98 & $11.47 \pm 5.95$ & $32.09 \pm 10.90$ & $7.72 \pm 2.28$ \\
\hline \multicolumn{2}{|c|}{ Total } & 147 & $21.52 \pm 14.47$ & $64.43 \pm 48.02$ & $6.33 \pm 2.66$ \\
\hline \multicolumn{2}{|c|}{ p value } & & 0.000 & 0.000 & 0.000 \\
\hline
\end{tabular}

Comparison was done by Mann-Whitney test and $p$-value was considered significant at $\mathrm{p} \leq 0.05$.

Table 4: Correlations between Cariogram, Oratest and dental caries experience.

\begin{tabular}{|l|c|c|}
\hline \multicolumn{1}{|c|}{ Correlation } & Spearman's correlation & p value \\
\hline Cariogram vs. Oratest & 0.887 & 0.000 \\
\hline Cariogram vs. Dental caries experience & -0.909 & 0.000 \\
\hline Oratest vs. Dental caries experience & -0.811 & 0.000 \\
\hline p-value was considered significant at $p \leq 0.05$. & \\
\hline
\end{tabular}

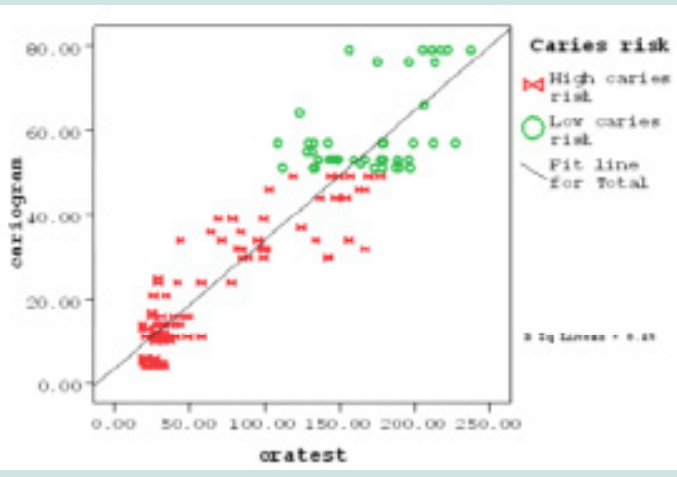

Figure 1: Correlation between Cariogram and Oratest.

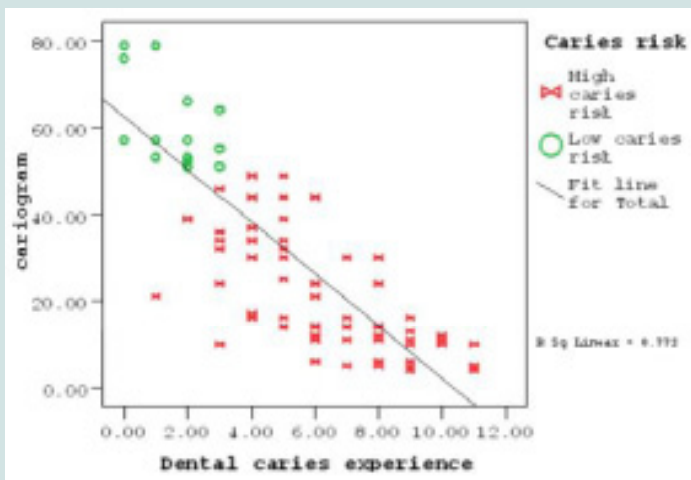

Figure 2: Correlation between green sector of Cariogram and dental caries experience.

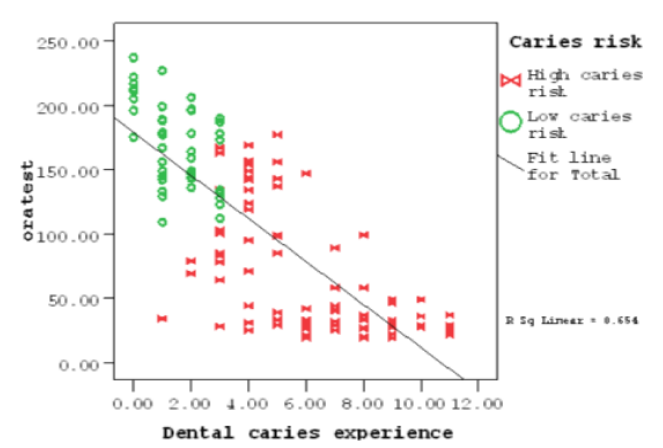

Figure 3: Correlation between Oratest and dental caries experience.

Table 5: The sensitivity and specificity of Cariogram and Oratest in relation to dental caries experience.

\begin{tabular}{|c|c|c|c|c|c|c|}
\hline \multirow{2}{*}{\begin{tabular}{|c|} 
Test \\
Risk level \\
$\begin{array}{c}\text { Caries } \\
\text { experience }\end{array}$ \\
\end{tabular}} & \multicolumn{3}{|c|}{ Cariogram } & \multicolumn{3}{|c|}{ Oratest } \\
\hline & $\begin{array}{c}\text { Worse } \\
\text { than } \\
\text { normal }\end{array}$ & $\begin{array}{c}\text { Normal and } \\
\text { better than } \\
\text { normal }\end{array}$ & Total & $\begin{array}{c}\text { Worse } \\
\text { than } \\
\text { normal }\end{array}$ & $\begin{array}{c}\text { Normal and } \\
\text { better than } \\
\text { normal }\end{array}$ & Total \\
\hline High risk & 125 & 22 & 147 & 113 & 17 & 130 \\
\hline Low risk & 4 & 89 & 93 & 16 & 94 & 110 \\
\hline Total & 129 & 111 & 240 & 129 & 111 & 240 \\
\hline Sensitivity & \multicolumn{3}{|c|}{$97 \%$} & \multicolumn{3}{|c|}{$88 \%$} \\
\hline Specificity & \multicolumn{3}{|c|}{$80 \%$} & \multicolumn{3}{|c|}{$85 \%$} \\
\hline
\end{tabular}

obtain the green sector [27].

The efficacy of Oratest as a simple chair side caries activity test was evaluated in previous studies where increased the amount of bacterial colonization lead to lesser the amount of time taken for the change in the color of methylene blue and vice versa, and thus it was inferred that Oratest provided a reliable estimate of the caries activity $[28,29]$. However, the literature about its comparative evaluation with other caries activity tests seems to be lacking. Hence, this study has been attempted to explore the correlation of simple oral rinse technique (Oratest) with an objective caries predictive technique (Cariogram) in school children.

The results of the present study indicated high significant differences between low caries risk and high caries risk individuals classified by Cariogram as regards different risk factors (Table 2), also, there was highly significant negative correlation between cariogram and past dental caries experience (Table 4). These results support the results obtained by previous studies which proved the usability of Cariogram in caries risk assessment [30,31].

The results of the present study indicated, individuals with Oratest time less than 64.43 minutes are at high caries risk and there were high significant differences between low caries risk and high caries risk individuals as regards Oratest scores (Table 3), also there was highly significant negative correlation between Oratest scores and past dental caries experience (Table 4), these results confirm the ability of Oratest to predict the caries susceptibility as these results support the results obtained by other studies which suggested the usability of Oratest as a caries risk assessment tool both at the individual level and 
community to identify person or groups of persons with an increased risk to develop caries [32,33].

The present study revealed high positive correlation between the scores of green sector of cariogram and Oratest scores (Table 4). Evidence was found that Oratest time was significantly higher in low risk individuals as well as negative correlations with dental caries experience was occurred [28,29]. Also, higher levels of cariogenic organisms and higher plaque values in high risk group may have resulted into shortest Oratest time [34,35].

Both Cariogram and Oratest are effective in prediction of caries risk as they have combination of sensitivity and specificity more than 160 percent and reaching the desired combination of sensitivity and specificity decided by previous studies approved different caries risk assessment tools (Table 5) [36,37]. It is important to consider this as it has been widely recognized that regardless of the accuracy of any caries risk assessment system, the data collection process for decision-making by the clinician needs to be quick, inexpensive, and be acceptable to those to whom it is applied [38]. Thus, in context to the observations of the present study and of earlier studies supported that Oratest can be used as tool to estimate caries activity.

\section{Conclusion}

The present study confirmed the ability of Oratest as simple, inexpensive and accurate risk assessment tool for detecting caries susceptibility on individual level as well as community level.

\section{References}

1. Milsom KM, Blinkhorn AS, Tickle M (2008) The incidence of dental caries in the primary molar teeth of young children receiving National Health Service funded dental care in practices in the North West of England. Br Dent J 205: E14

2. Bagramian RA, Garcia-Godoy F, Volpe AR (2009) The global increase in dental caries. A pending public health crisis. Am J Dent 22: 3-8.

3. Maheswari SU, Raja J, Kumar A, Seelan RG (2015) Caries management by risk assessment: a review on current strategies for caries prevention and management. J Pharm Bioallied Sci 7 (Suppl 2): S320-S324.

4. Bratthall D, Hänsel Petersson G (2005) Cariogram--a multifactorial risk assessment model for a multifactorial disease. Community Dent Ora Epidemiol 33: 256-264

5. Chaffee BW, Cheng J, Featherstone JD (2015) Baseline caries risk assessment as a predictor of caries incidence. J Dent 43: 518-524.

6. van Houte J (1993) Microbiological predictors of caries risk. Adv Dent Res 7: 87-96.

7. Motohashi M, Yamada H, Genkai F, Kato H, Imai T, et al. (2006) Employing $\mathrm{dmft}$ score as a risk predictor for caries development in the permanent teeth in Japanese primary school girls. J Oral Sci 48: 233-237.

8. Tal H, Rosenberg M (1990) Estimation of dental plaque levels and gingival inflammation using a simple oral rinse technique. J Periodontol 61: 339-342.

9. Patalay A, Shubhada C, Nadiger SL (1996) Oratest:--a simple, chair-side caries activity test. J Indian Soc Pedod Prev Dent 14: 6-9.

10. Bhasin S, Sudha P, Anegundi RT (2006) Chair side simple caries activity test: ora test. J Indian Soc Pedod Prev Dent 24: 76-79.
11. American Dental Association (1995). Caries diagnosis and risk assessment A review of preventive strategies and management. J Am Dent Assoc 126 Suppl: 1S-24S.

12. Hänsel Petersson G, Twetman S, Bratthall D (2002) Evaluation of a computer program for caries risk assessment in schoolchildren. Caries Res 36: $327-$ 340.

13. Petersson GH (2003) Assessing caries risk--using the Cariogram model. Swed Dent J Suppl: 1-65.

14. Tellez M, Gomez J, Pretty I, Ellwood R, Ismail Al (2013) Evidence on existing caries risk assessment systems: are they predictive of future caries? Community Dent Oral Epidemiol 41: 67-78.

15. Holgerson PL, Twetman S, Stecksen-Blicks C (2009) Validation of an agemodified caries risk assessment program (Cariogram) in preschool children Acta Odontol Scand 67: 106-112.

16. Campus G, Cagetti MG, Sale S, Carta G, Lingström P (2012) Cariogram validity in school children: a two-year follow-up study. Caries Res 46: 16-22.

17. WHO (1997) Oral health surveys: basic methods $\left(4^{\text {th }} e d n\right)$. World Health Organization, Geneva, Switzerland.

18. Klein H, Palmer CE, Knutson JW (1938) Studies on dental caries: I. Dental status and dental needs of elementary school children. Public Health Rep 53: 751-765.

19. Gruebbel AO (1944) A measurement of dental caries prevalence and treatment services for deciduous teeth. J Dent Res 23: 163-168.

20. Silness J, Löe H (1964) Periodontal disease in pregnancy. II. Correlation between oral hygiene and periodontal condition. Acta Odontol Scand 22: 121-135.

21. Dawes C, Tsang RW, Suelzle T (2001) The effects of gum chewing, four oral hygiene procedures, and two saliva collection techniques, on the output of bacteria into human whole saliva. Arch Oral Biol 46: 625-632.

22. Rosenberg M, Barki M, Portnoy S (1989) A simple method for estimating ora microbial levels. J Microbiol Methods 9: 253-256.

23. Cabral RN, Hilgert LA, Faber J, Leal SC (2014) Caries risk assessment in schoolchildren--a form based on Cariogram software. J Appl Oral Sci 22: 397-402.

24. Celik EU, Gokay N, Ates M (2012) Efficiency of caries risk assessment in young adults using Cariogram. Eur J Dent 6: 270-279.

25. Petersson GH, Twetman S (2015) Caries risk assessment in young adults: a 3 year validation of the Cariogram model. BMC Oral Health 15: 17

26. Alian AY, McNally ME, Fure S, Birkhed D (2006) Assessment of caries risk in elderly patients using the Cariogram model. J Can Dent Assoc 72: 459-463.

27. Kemparaj U, Chavan S, Shetty NL (2014) Caries Risk Assessment among School Children in Davangere City Using Cariogram. Int J Prev Med 5: 664671

28. Saxena S, Pundir S, Aena J (2013) Oratest: a new concept to test caries activity. J Indian Soc Pedod Prev Dent 31: 25-28.

29. Sundaram M, Nayak UA, Ramalingam K, Reddy V, Rao AP, et al. (2013) A comparative evaluation of oratest with the microbiological method of assessing caries activity in children. J Pharm Bioallied Sci Sci 5 (Suppl 1): S5-S9.

30. Giacaman RA, Miranda Reyes P, Bravo Leön V (2013) Caries risk assessment in Chilean adolescents and adults and its association with caries experience. Braz Oral Res 27: 7-13.

31. Karabekiroglu S, Ünlü N (2017) Effectiveness of different preventive programs in Cariogram parameters of young adults at high caries risk. Int $\mathrm{J}$ Dent 2017: 1-10.

32. Jindal R, Dua R, Sachdeva J (2016) Evaluation of caries activity by oratest 
Int J Enhanc Res Med Dent Care 3: 6-10.

33. Chandak S, Kesri R, Bhardwaj A (2016) Milk, a simple tool to detect caries activity: oratest. Int J Prev Clin Dent Res 3: 98-101.

34. Joshi M, Jayakrumar, Joshi N (2012) Comparative evaluation for assessing oratest as a diagnostic tool for evaluation of plaque levels and gingivitis. $J$ Dent Allied Sci 1: 52-56.

35. Kunte SS, Chaudhary S, Singh A, Chaudhary M (2013) Evaluation and corelation of the oratest, colorimetric Snyder's test and salivary Streptococcus mutans count in children of age group of 6-8 years. J Int Soc Prev Community Dent 3: 59-66.
36. Gao XL, Hsu CY, Xu Y, Hwarng HB, Loh T, et al. (2010) Building caries risk assessment models for children. J Dent Res 89: 637-643.

37. Kingman A, Little W, Gomez I, Heifetz SB, Driscoll WS, et al. (1988) Salivary levels of Streptococcus mutans and lactobacilli and dental caries experiences in a US adolescent population. Community Dent Oral Epidemiol 16: 98-103.

38. Stamm JW, Disney JA, Graves RC, Bohannan HM, Abernathy JR (1988) The University of North Carolina caries risk assessment study I: rationale and content. J Public Health Dent 48: 225-232.

Acknowledgements

Special thanks to Dr. Margarida Sousa Menezes, DDS for her contribution of clinical cases and revision of the manuscript. 